\title{
Redactioneel
}

\section{Omgevingswet: maak de ambities waar, maar maak het niet ingewikkelder dan het al} is

Prof. mr. A.G.A. (Tonny) Nijmeijer*

Op 3 december 2015 verscheen het advies Vernieuming omgevingsrecht: maak de ambities waar van de Raad voor de leefomgeving en infrastructuur (hierna: Rli). In dit raadsadvies staat de vraag centraal in hoeverre het wetsvoorstel Omgevingswet leidt tot een verwezenlijking van de doelen die de regering zich met de stelselherziening in het omgevingsrecht heeft gesteld. ${ }^{1}$ De Rli constateert dat het wetsvoorstel op onderdelen beter kan en doet interessante aanbevelingen voor verbetering. ${ }^{2}$ De anbevelingen hebben ook betrekking op de nog vast te stellen vier algemene maatregelen van bestuur (hierna: AMvB's) en op de uitvoeringspraktijk. ${ }^{3}$ Het is de bedoeling dat de AMvB's in de eerste helft van 2016 in de openbare consultatie worden gebracht. ${ }^{4}$ De timing van de Rli is dus fraai.

Het raadsadvies heeft twee hoofdlijnen. De eerste betreft de nationale omgevingsvisie die het Rijk op basis van art. 3.1 lid 3 van de Omgevingswet vaststelt. De Rli beveelt een nationale omgevingsvisie aan die 'inspirerend én selectief' is. Inspirerend is volgens de Rli een omgevingsvisie die alle betrokkenen bij het omgevings-

* Prof. mr. A.G.A. Nijmeijer is hoogleraar omgevingsrecht aan de Radboud Universiteit en verbonden aan Hekkelman Advocaten te Nijmegen. Op verzoek van de redactie heeft de auteur dit gastredactioneel geschreven.

1. Vernieuwing omgevingsrecht: maak de ambities waar, p. 10.

2. De verwachting is dat de Invoeringswet Omgevingswet - ook los van het advies van de $\mathrm{Rli}$ - zal worden aangegrepen om een aantal wijzigingen in de Omgevingswet aan te brengen.

3. Het betreft: Omgevingsbesluit, Besluit bouwwerken leefomgeving, Besluit kwaliteit leefomgeving en Besluit activiteiten leefomgeving.

4. Zie voor de planning van de stelselherziening: H.A.J. Gierveld, Verder werken aan de Omgevingswet, TO 2015, afl. 4, p. 149-151. beleid uitdaagt om bij te dragen aan de aanpak van de belangrijkste opgaven in de leefomgeving. ${ }^{5}$ Dat klinkt goed en tegelijkertijd vaag. Op het punt van selectiviteit is het raadsadvies concreter. Het formuleert vijf selectiecriteria voor in de nationale omgevingsvisie te adresseren beleidsthema's. ${ }^{6}$ Criteria als 'er moet sprake zijn van toepassing van het subsidiariteitsprincipe' en 'er moet sprake zijn van toegevoegde waarde voor nationale welvaart en welzijn' zijn rekkelijk. Op basis van de selectiecriteria noemt de Rli echter vier thema's die het Rijk in de nationale omgevingsvisie moet aansnijden: energietransitie, klimaatadaptie, verbeteren van ruimtelijk-economische structuur en transformatie van het landelijk gebied. Dat zijn nog steeds betrekkelijk ruime aandachtspunten; bovendien kan de vraag worden gesteld waarom juist deze onderwerpen, en of het rijtje volledig is. Dat laat onverlet dat de oproep tot selectiviteit verstandig is. Want net als de structuurvisies in de Wet ruimtelijke ordening (Wro), is de (nationale) omgevingsvisie niet bindend voor burgers (of medeoverheden). Er gaat enige 'zelfbinding' van uit, maar die moet niet worden overschat. ${ }^{7}$ De zwakke juridische status vergroot het risico op een omgevingsvisie die een beleidsmatige ratjetoe wordt (sommige Wro-structuurvisies zijn daar prangende voorbeelden van). Dat risico wordt vergroot door het brede belangenspectrum waarop de omgevingsvisie - door de ruime omschrijving van

5. Vernieuwing omgevingsrecht: maak de ambities waar, p. 26

6. Vernieuwing omgevingsrecht: maak de ambities waar, p. 28.

7. Afwijken van een structuurvisie is toegestaan, mits die afwijking deugdelijk wordt gemotiveerd. Die motivering wordt marginaal door de bestuursrechter getoetst. Daarover uitgebreid P.J.J. van Buuren e.a., Hoofdlijnen ruimtelijk bestuursrecht, Deventer: Wolters Kluwer 2014, hoofdstuk 2. 
hetgeen onder de fysieke leefomgeving wordt verstaan betrekking kan hebben. ${ }^{8}$ Beleidsmatige selectiviteit is dan een (extra) groot goed.

De tweede hoofdlijn in het raadsadvies betreft de zoektocht naar meer flexibiliteit in het omgevingsrecht. In dat kader beveelt de Rli onder meer aan om in het Besluit kwaliteit leefomgeving terughoudend te zijn met niet-afweegbare, 'harde' normen. ${ }^{9}$ De voorkeur van de Rli gaat uit naar zo veel mogelijk 'nader afweegbare' normen. Daar zit een zwakke stee in het raadsadvies, vind ik. Los van het feit dat de Rli onvoldoende inzichtelijk maakt wat in deze context precies het verschil is tussen niet-afweegbare en nader afweegbare normen gaat het bijvoorbeeld om het verschil tussen grenswaarden en richtwaarden of is een fijnmaziger onderscheid bedoeld? - wijst het raadsadvies in relatie tot nietafweegbare normen op het ontstaan van hoge onderzoekslasten en lange besluitvormingstrajecten als aan dergelijke normen niet kan worden voldaan. Mijn ervaring is dat uitbundig onderzoek en (dus) complexe en tijdrovende besluitvorming vooral aan de orde zijn bij normen die het bevoegd gezag discretionaire ruimte bieden. Als de norm kwantitatief is en er niks af te wegen valt - bijvoorbeeld een in acht te nemen grenswaarde ingevolge het Activiteitenbesluit milieubeheer ${ }^{10}-$ dan zijn het onderzoek en de besluitvorming betrekkelijk overzichtelijk. Opmerkelijk genoeg zegt de Rli dat zelf ook, maar spreekt hij toch de voorkeur uit voor nader afweegbare normen. ${ }^{11}$ Die voorkeur lijkt daarom met name ingegeven door het pleidooi dat de Rli houdt voor meer flexibiliteit in omgevingsrechtelijke normstelling. In het raadsadvies wordt daartoe een nuttige 'denkladder voor normstelling' geïntroduceerd en wordt een uniforme structuur voor normstelling gepresenteerd. ${ }^{12}$ Met name die uniforme structuur verdient serieuze overdenking, maar te voorzien valt dat een omgevingsrechtbrede toepassing veel tijd vergt. Enkel tijdsdruk zou echter geen reden mogen zijn om dit idee links te laten liggen. De tijd die gemoeid is met het op een uniforme nieuwe leest schoeien van omgevingsrechtelijke normen, zou zich best kunnen terugbetalen in aanzienlijke tijdwinst bij het toepassen van de normen in de uitvoeringspraktijk.

Minder enthousiast ben ik over het pleidooi van de Rli om de Omgevingswet te voorzien van een 'balansbepaling'. ${ }^{13}$ Deze figuur doet mij denken an de 'positieve evenredigheid' die in het voorontwerp van het wetsvoorstel Omgevingswet was opgenomen. ${ }^{14}$ De balansbe-

8. Zie de niet-limitatieve opsomming in art. 1.2 Omgevingswet.

9. Vernieuwing omgevingsrecht: maak de ambities waar, p. 43. Voor zover een 'harde' norm direct voortvloeit uit dwingend Europees recht, is de keus voor nader afweegbare normen voor onze wetgever natuurlijk niet aan de orde.

10. Bijv. ABRvS 29 april 2015, 201407417/1/R3 (Bergen op Zoom).

11. Vernieuwing omgevingsrecht: maak de ambities waar, p. 43.

12. Vernieuwing omgevingsrecht: maak de ambities waar, p. 45-46.

13. Vernieuwing omgevingsrecht: maak de ambities waar, p. 52.

14. Daarover o.a. B.J. Schueler, Of heeft u liever negatieve evenredigheid?, $M$ en R 2012/47. Volgens de Rli is de balansbepaling iets anders dan de positieve evenredigheid. paling maakt het kort gezegd mogelijk dat op een bepaalde locatie een verslechtering van een bepaalde kwaliteit van de leefomgeving - bijvoorbeeld de geluidsbelasting op een gevoelig object - wordt 'weggestreept' tegen een verbetering van de kwaliteit van de fysieke leefomgeving als geheel. ${ }^{15}$ Het voordeel van zo'n balansbepaling - veel flexibiliteit voor het bevoegd gezag én de ontwikkelende partij(en) - weegt naar mijn voorlopige oordeel niet op tegen de nadelen die ik onder meer zie in een afdoende borging van de belangen van derden. Ook de vraag wanneer en onder welke randvoorwaarden een belanghebbende kan verzoeken om toepassing van de balansbepaling (inclusief bijbehorende bestuursrechtelijke rechtsbescherming omtrent een beslissing op zo'n verzoek), leidt naar mijn verwachting alras tot een dermate gecompliceerde wettelijke regeling dat de eventuele winst van een balansbepaling verdampt. Daar komt bij dat als het gaat om in een omgevingsplan door de gemeentelijke planwetgever geformuleerde omgevingswaarden, bijvoorbeeld met betrekking tot geluid of stank, het bevoegd gezag de mogelijkheid heeft om door middel van een omgevingsvergunning van die onderdelen van een omgevingsplan af te wijken. ${ }^{16}$ In zoverre voorziet het wetsvoorstel Omgevingswet dus al in een 'balansbepaling'.

Over het omgevingsplan zegt de Rli nog een paar opvallende dingen. Zo pleit hij voor het kunnen opnemen van gebodsbepalingen in een omgevingsplan. Het gaat dan om echte verplichtingen, bijvoorbeeld tot het bouwen van een woning of tot het omzetten van agrarische gronden in natuurgronden (indien nodig onder aanbieding van nadeelcompensatie). ${ }^{17}$ Elders heb ik deze aanbeveling belicht. ${ }^{18}$ Ik herhaal op deze plaats dat de toegevoegde waarde van dit soort gebodsbepalingen naar mijn verwachting beperkt is omdat een omgevingsplanregel evenredig moet zijn. ${ }^{19}$ Van evenredigheid kan mijns inziens per definitie geen sprake zijn als een planregel bij voorbaat onuitvoerbaar moet worden geacht. Om die reden verwacht ik dat onder de Omgevingswet - ook als een omgevingsplan gebodsbepalingen zou mogen bevatten - onteigening de aangewezen weg blijft voor de overheid om ontwikkelingen in de fysieke leefomgeving daadwerkelijk te realiseren. Dat neemt niet weg dat een gebodsbepaling in een omgevingsplan nodig kan zijn. Denk aan gevallen waarin naar huidig recht verplichtingen met betrekking tot de fysieke leefomgeving worden opgelegd in lokale verordeningen (bijvoorbeeld het plegen van onderhoud aan open terreinen of bomen). De regels uit deze verordeningen zullen ingevolge art. 4.1

15. In het raadsadvies (p. 50-51) wordt in dit verband de herontwikkeling van een havenlocatie ten behoeve van een woningbouwfunctie genoemd.

16. Art. 5.1 lid 1 onder b Omgevingswet.

17. Vernieuwing omgevingsrecht: maak de ambities waar, p. 64.

18. Zie mijn bijdrage Omgevingswet. Gebodsbepalingen in het omgevingsplan: (veel) eenvoudiger gezegd dan gedaan, TBR 2015/185.

19. Voor regels die functies toewijzen aan locaties spreekt art. 4.2 Omgevingswet over 'evenwichtig'. Voor overige planregels volgt de eis van evenredigheid uit art. 3:4 lid 2 Awb. 
van de Omgevingswet in het omgevingsplan moeten worden opgenomen. ${ }^{20}$

Tot besluit een enkele opmerking over 'planafspraken'. De Rli beveelt aan om in de Omgevingswet een wettelijke grondslag voor het maken van planafspraken op te nemen. ${ }^{21}$ Planafspraken worden genoemd in relatie tot een globale inhoud van omgevingsplannen, met name als het de toedeling van functies aan locaties betreft. Door middel van een planafspraak tussen de gemeente en bijvoorbeeld de aanvrager van een omgevingsvergunning voor bouwen kan een globale omgevingsplanregeling nader worden ingevuld. ${ }^{22}$ In die vorm doet de planafspraak denken aan een globaal bestemmingsplan met uitwerkingsplicht. Een vergelijkbare planfiguur, die kan worden gegoten in een omgevingswettelijke variant waarbij de nadere invulling van het omgevingsplan op basis van een delegatiebesluit geschiedt door het college van burgemeester en wethouders, heeft mijn sterke voorkeur boven het novum van de planafspraak zoals de Rli voorstelt.

De Rli geeft aan dat de idee van de wettelijke grondslag voor de planafspraak mede is ingegeven om de geoorloofdheid van dergelijke afspraken buiten twijfel te stellen. ${ }^{23}$ Naar huidig recht schuilt de angel bij bevoegdhedenovereenkomsten waarbij afspraken zijn gemaakt over de inhoud van een vast te stellen bestemmingsplan voor een belangrijk deel in de (afwezigheid van) betrokkenheid van derden bij die overeenkomst. ${ }^{24}$ De bevoegdhedenovereenkomst laat onverlet dat in het publiekrechtelijke besluitvormingstraject alle relevante belangen moeten worden gewogen, dus ook de belangen van derden die niet bij de contractsvorming zijn betrokken. Dat kan ertoe leiden dat het bestemmingsplan een inhoud krijgt die niet overeenstemt met hetgeen contractueel is vastgelegd. ${ }^{25}$ Het is naar mijn mening niet wenselijk dat een omgevingsplan straks globaal blijft en de concrete inhoud in een planafspraak wordt vastgelegd waarbij derden niet betrokken hoeven worden. Waar de Rli opmerkt dat 'goed denkbaar' is dat derden bij de planafspraak worden betrokken, ${ }^{26}$ vind ik dat een absolute voorwaarde als het gaat om burgers bindende regels omtrent het beschermen en benutten van de fysieke leefomgeving. De omgevingsplanprocedure die is voorgeschreven in hoofdstuk 16 van de Omgevingswet, biedt daartoe het geëigende, publiekrechtelijke instrumentarium (afdeling 3.4 van de Algemene wet bestuursrecht (Awb) is van toepassing). Het optuigen van een daarvan

20. A.E. Kneepkens, K. Krijt \& B. Rademaker, Het omgevingsplan, TBR 2014/164, i.h.b. par. 3 en 4.

21. Vernieuwing omgevingsrecht: maak de ambities waar, p. 59.

22. Het raadsadvies noemt het voorbeeld van een functie 'groene woonwijk' zonder dat in het omgevingsplan exact is bepaald op welke locatie de functie 'wonen' rust en op welke locatie de functie 'groen'.

23. Vernieuwing omgevingsrecht: maak de ambities waar, p. 60.

24. Zie o.a. H.Ph.J.A.M. Hennekens, Enkele knellende punten in de gemeentelijke structuur. De raad en het college van B\&W in de ruimtelijke ordening, TBR 2015/173.

25. Vgl. o.a. HR 8 juli 2011, ECLI:NL:HR:2011:BP3057 (Etam c.s./Zoetermeer).

26. Vernieuwing omgevingsrecht: maak de ambities waar, p. 60. losstaand contractueel spoor vertroebelt het publiekrechtelijke systeem nodeloos en is onnodig gelet op de delegatiemogelijkheid die de Omgevingswet in art. 2.8 bevat. De oproep van de Rli om met de Omgevingswet de ambities voor een eenvoudiger en beter omgevingsrecht waar te maken verdient waardering, maar gewaakt moet worden voor een Omgevingswet die nog ingewikkelder wordt dan zij nu al is. 